\title{
PANDANGAN IMAM MAZHAB TENTANG HAK ISTRI PADA MASA IDDAH TALAK BAIN DAN REVALANSINYA DENGAN PERATURAN PERUNDANG-UNDANGAN DI INDONESIA
}

\author{
Riyan Erwin Hidayat
}

\begin{abstract}
ABSTRAK
Setiap manusia menginginkan kebahagiaan, salah satu kebahagiaan yang dapat dicapai adalah dengan cara menikah, akan tetapi membina keluarga yang harmonis tidaklah mudah, karena akan muncul berbagai permasalahan dalam rumah tangga. Dan apabila masalah tersebut tidak dapat terselesaikan, maka percerain menjadi satu-satunya jalan keluar yang terakhir. Dengan terjadinya perceraian, akan ada masa tunggu bagi perempuan yang disebut masa iddah, di mana dalam masa iddah ini, istri wajib mendapatkan haknya seperti hak nafkah.

Fiqh madzhab (Hanafi, Maliki, Syafi'i dan Hambali) sepakat bahwa perempuan yang diceraikan dalam bentuk talak raj'i, berhak mendapatkan nafkah dan tempat tinggal selama masa iddah. Berbeda dengan Peraturan Pemerintah Nomor 10 Tahun 1983 tentang Izin Perkawinan dan Perceraian Pegawai Negeri Sipil, yang mengatur tentang nafkah dalam hal ini adalah pasal 8 tentang pembagian gaji, yang diberikan mantan suaminya terhadap mantan istrinya tersebut.

Berdasarkan pernyataan di atas, maka kajian terhadap hak nafkah janda yang tidak menikah lagi menjadi menarik dan sangat penting, hal ini dikarenakan adanya perbedaan antara hukum Islam (pendapat fiqh mazhab) dengan peraturan pemerintah. Dalam hal ini penulis ingin meneliti lebih dalam tentang persamaan dan perbedaan diantara keduannya.

Jenis penelitian yang penulis gunakan adalah penelitian pustaka (library research), dengan objek penelitiannya adalah pendapat fiqh madzhab dan peraturan pemerintah. Sumber data yang penulis gunakan adalah data sekunder yaitu data yang diperoleh dari buku-buku, dokumen dan lainnya. Teknik pengumpulan data yang penulis gunakan yaitu teknik dokumentasi yang digunakan untuk mengumpulkan serta meneliti bahan pustaka, yang merupakan data sekunder dari judul dan permasalahan dalam penelitian ini, sedangkan teknik analisis dalam penelitian ini adalah analisis komparatif yaitu menganalisis serta membandingkan persamaan dan perbedaan pendapat fiqh mazhab dan peraturan pemerintah. Dalam penelitian ini, metode pendekatan yang digunakan adalah yuridis normatif, yaitu dengan cara menganalisa data yang diperoleh dengan ketentuan hukum.

Dari studi perbandingan hukum Islam (pendapat fiqh mazhab) dan Peraturan Pemerintah Nomor 10 Tahun 1983 tentang Izin Perkawinan dan Perceraian Pegawai Negari Sipil, diharapkan ke depannya untuk lebih memikirkan nasib semua janda, dalam hal nafkah khususnya setelah masa iddah. Sehingga tidak hanya mantan istri pegawai negeri sipil saja yang mendapatkan hak nafkah setelah masa iddah.
\end{abstract}




\section{A. Kata Pengantar}

Setiap manusia menginginkan kebahagiaan, salah satu kebahagiaan yang dapat dicapai adalah dengan cara menikah, akan tetapi membina keluarga yang harmonis tidaklah mudah, karena akan muncul berbagai permasalahan dalam rumah tangga. Dan apabila masalah tersebut tidak dapat terselesaikan, maka percerain menjadi satu-satunya jalan keluar yang terakhir. Dengan terjadinya perceraian, akan ada masa tunggu bagi perempuan yang disebut masa iddah, di mana dalam masa iddah ini, istri wajib mendapatkan haknya seperti hak nafkah.

Fiqh madzhab (Hanafi, Maliki, Syafi'i dan Hambali) sepakat bahwa perempuan yang diceraikan dalam bentuk talak raj'i, berhak mendapatkan nafkah dan tempat tinggal selama masa iddah. Berbeda dengan Peraturan Pemerintah Nomor 10 Tahun 1983 tentang Izin Perkawinan dan Perceraian Pegawai Negeri Sipil, yang mengatur tentang nafkah dalam hal ini adalah pasal 8 tentang pembagian gaji, yang diberikan mantan suaminya terhadap mantan istrinya tersebut.

Berdasarkan pernyataan di atas, maka kajian terhadap hak nafkah janda yang tidak menikah lagi menjadi menarik dan sangat penting, hal ini dikarenakan adanya perbedaan antara hukum Islam (pendapat fiqh mazhab) dengan peraturan pemerintah. Dalam hal ini penulis ingin meneliti lebih dalam tentang persamaan dan perbedaan diantara keduannya.

Jenis penelitian yang penulis gunakan adalah penelitian pustaka (library research), dengan objek penelitiannya adalah pendapat fiqh madzhab dan peraturan pemerintah. Sumber data yang penulis gunakan adalah data sekunder yaitu data yang diperoleh dari buku-buku, dokumen dan lainnya. Teknik pengumpulan data yang penulis gunakan yaitu teknik dokumentasi yang digunakan untuk mengumpulkan serta meneliti bahan pustaka, yang merupakan data sekunder dari judul dan permasalahan dalam penelitian ini, sedangkan teknik analisis dalam penelitian ini adalah analisis komparatif yaitu menganalisis serta membandingkan persamaan dan perbedaan pendapat fiqh mazhab dan peraturan pemerintah. Dalam penelitian ini, metode pendekatan yang digunakan adalah yuridis normatif, yaitu dengan cara menganalisa data yang diperoleh dengan ketentuan hukum.

Dari studi perbandingan hukum Islam (pendapat fiqh mazhab) dan Peraturan Pemerintah Nomor 10 Tahun 1983 tentang Izin Perkawinan dan Perceraian Pegawai Negari Sipil, diharapkan ke depannya untuk lebih memikirkan nasib semua janda, dalam hal nafkah khususnya setelah masa iddah. Sehingga tidak hanya mantan istri pegawai negeri sipil saja yang mendapatkan hak nafkah setelah masa iddah.

\section{B. Nafkah Iddah Menurut Hukum Islam}

\section{Pengertian Nafkah Iddah}

Nafkah iddah adalah pemberian suami kepada istri, berupa belanja untuk keperluan hidupnya, selama menjalani masa iddah akibat talak yang dijatuhkan kepadanya. ${ }^{1}$ Menurut madzhab fiqh (Hanafi, Maliki,

\footnotetext{
${ }^{1}$ Slamet Abidin dan Aminuddin, Fiqih Munakahat, Bandung, Pustaka Setia, 1999, Hal
} 141. 
Syafi'i dan Hambali), nafkah iddah ialah pemberian suami berupa nafkah dan tempat tinggal yang diterima istri ketika menjalani masa iddah. ${ }^{2}$ Jadi dapat dipahami bahwa istri berhak mendapatkan nafkah dan tempat tinggal, dari suaminya selama masa iddah berlangsung khususnya talak raj'i.

Nafkah iddah ini berupa nafkah dan maskan (tempat tinggal), Hanafi, Maliki dan Hambali berpendapat nafkah yang diberikan suami kepada istri tidak memiliki batasan, menurut hukum syara', ${ }^{4}$, tetapi lebih diukur menurut keadaan suami istri. ${ }^{5}$ Sedangkan Syafi'i menentukan nafkah perharinya 1 mud untuk orang miskin, satu setengah mud untuk orang yang sedang dan untuk orang kaya 2 mud, tentunya nafkah iddah ini sama dengan nafkah istri sebelum perceraian, dengan dalih, wanita yang ditalak dan dapat dirujuk oleh suaminya masih menempati posisi sebagai istri, dimana suami berkewajiban memberi nafkah dan tempat tinggal. $^{6}$

\section{Pendapat Madzhab Fiqh Mengenai Nafkah Iddah}

Pendapat madzhab fiqh mengenai nafkah dan tempat tinggal pada masa iddah, dalam bentuk talak raj'i atau talak bain, mempunyai persaamaan dan perbedaan di antaranya yaitu :

Madzhab Hanafi menyatakan, kewajiban nafkah kepada istri yang dicerai dengan talak raj'i maupun ba'in, ia tetap berhak atas nafkah dan tempat tinggal dari suaminya selama istri tersebut, tidak meninggalkan tempat tinggal yang disediakan oleh suaminya dan akibat tertahannya dia pada masa iddah demi hak suami ini berlaku untuk istri yang hamil atau tidak.

Madzhab Maliki menyatakan bahwa perempuan yang diceraikan dengan bentuk talak raj'i berhak mendapatkan hak nafkah dan tempat tinggal. ${ }^{8}$ Lebih lanjut Imam Malik menyebutkan bahwa hak tempat tinggal berlaku untuk bentuk perceraian dengan talak raj'i ataupun ba'in selama masa iddah, berdasarkan firman Allah dalam surat At-Talak ayat 6 yaitu "tempatkanlah mereka (para istri) di mana kamu bertempat tinggal”. tetapi untuk hal nafkah istri tidak mendapatkannya sama sekali.

${ }^{2}$ Wahbah az-Zuhaili, Fiqih Islam Wa Adilatuhu, alih bahasa Abdul Hayyie al-Kattani, et.al, Jakarta, Darul Fikir, 2011 Hal 562

${ }^{3}$ Ibnu Rusyd, Bidayatul Mujtahid, alih bahasa Imam Ghazali Said dan Achmad Zainudin ,Jakarta, Pustaka Amani, 2007, Hal 614

${ }_{5}^{4}$ Ibid Hal 204

${ }^{5}$ Syaikh Al-Allamah Muhammad, Fiqh Empat Mazhab alih bahasa Abdullah Zaki Alkaf, Bandung, Hasyimi, 2010 Hal 388

6 Imam Syafi'i, Ringkasan Al Umm, alih bahasa Imron Rosadi, et.al, Jakarta, Pustaka Azzam, 2012 Hal 601

${ }^{7}$ Muhammad Jawad Mughniyah, Fiqh Lima Mazhab, alih bahasa Masykur et.al, Jakarta, Lentera, 2011 hal 401. 2006 hal 819

${ }^{8}$ Malik bin Anas, Al-Muwaththa', alih bahasa Nur Alim, et.al, Jakarta, Pustaka Azzam,

Ibnu Rusyd, Op.cit, Hal 616. 
Madzhab Syafi'i membahas tentang hak nafkah dan tempat tinggal bagi perempuan yang menjalani masa iddah, bahwa hak tempat tinggal berlaku untuk umum, yaitu semua bentuk perceraian. ${ }^{10}$ Adapun hak nafkah menurut Imam Syafi'i hanya berlaku pada perempuan yang diceraikan dengan bentuk perceraian yang dimungkinkan adanya ruju' antara pasangan suami istri yaitu talak raj'i, sedang dalam hal nafkah untuk istri yang tidak hamil dan tertalak ba'in, tidak berhak mendapatkan makanan dan pakaian dari suami, ini berdasarkan firman Allah SWT,"jika mereka (istri-istri yang sudah ditalak) itu sedang hamil, maka berikanlah kepada mereka nafkahnya hingga mereka bersalin". Pemahaman ayat ini menunjukan bagi ketidak wajiban pemberian nafkah bagi istri yang tidak hamil.

Imam Ahmad menyatakan bahwa hak nafkah dan tempat tinggal khusus bagi perempuan yang diceraikan dengan talak raj'i. Sehingga perempuan yang diceraikan dengan talak ba'in sama sekali tidak mendapatkan nafkah ataupun tempat tinggal.

Kesimpulan dari keterangan di atas adalah semua ulama mazhab sepakat bahwa perempuan yang diceraikan dalam bentuk talak raj'i, berhak mendapatkan nafkah dan tempat tinggal dari suaminya selama masa iddah. Sedangkan talak ba'in ulama berbeda pendapat yang dapat dikategorikan menjadi tiga kategori, yaitu:

1) Tidak berhak atas nafkah, tetapi mendapatkan hak tempat tinggal adalah pendapat madzhab Maliki dan Syafi'i.

2) Berhak atas nafkah dan tempat tinggal adalah pendapat Madzhab Hanafi.

3) Tidak diwajibkan memberi nafkah dan tempat tinggal adalah pendapat madzhab Hambali.

\section{Pengertian Nafkah Iddah Menurut KHI}

Kompilasi hukum Islam juga mengatur tentang pemberian nafkah mantan suami, kepada mantan istrinya tersebut karena talak, yaitu pada pasal 149 ayat (a) dan (b) : wajib:

Bilamana perkawinan putus karena talak, maka bekas suami

a. Memberikan mut'ah yang layak kepada bekas istrinya, baik berupa uang atau benda, kecuali bekas istri tersebut qobla al dukhul;

b. Memberi nafkah, maskan dan kiswah kepada bekas istri selama dalam iddah, kecuali bekas istri telah dijatuhi talak ba'in atau nusyuz dan dalam keadaan tidak hamil.

\footnotetext{
${ }^{10}$ Wahbah Zuhaili, al-Fiqhu Asy-Syafi'i al-Muyassar alih bahasa Muhammad Afifi dan
} Abdul Hafiz, Jakarta, Almahira, 2010, hal 21

${ }_{11}^{11}$ Wahbah az-Zuhaili, Fiqih Islam Wa Adilatuhu, Op.cit Hal 563.

${ }_{13}^{12}$ Ibid, hal 563.

${ }^{13}$ Abdurrahman, Kompilasi Hukum Islam, Jakarta, Akapress, 2010 Hal 149 
Pemberian nafkah iddah juga tercantum pada pasal 152 yang berbunyi, bekas istri berhak mendapat nafkah iddah dari bekas suaminya, kecuali bila ia nusyuz. ${ }^{14}$ Selain mendapatkan nafkah iddah, istri yang tertalak juga mendapatkan mut'ah, mut'ah adalah pemberian bekas suami kepada istri yang dijatuhi talak berupa benda atau uang dan lainnya. Hal ini didasarkan pada KHI 158 :

Mut'ah wajib diberikan oleh pihak suami dengan syarat:

a. Belum ditetapkan mahar bagi istri ba'da al dukhul;

b. Perceraian itu atas kehendak suami.

Kompilasi Hukum Islam juga mengatur besarnya mut'ah yang di atur pada pasal 160 yang berbunyi : suami".

"Besarnya mut'ah disesuaikan dengan kepatutan dan kemampuan

Berdasarkan keterangan di atas, jelaslah sudah bahwa istri berhak mendapatlan nafkah ketika menjalani masa iddah dan juga mut'ah, dari pihak suami yang menceraikannya.

\section{B. Hak Nafkah Janda Menurut PP Nomor 10 Tahun 1983}

1. Pengertian Nafkah Janda Menurut PP Nomor 10 Tahun 1983 Nafkah adalah uang belanja yang diberikan kepada istri atau ongkos hidup sehari-hari. ${ }^{17}$ Dalam undang-undang nafkah dikategorikan kewajiban suami kepada istri yang harus dipenuhi, seperti keperluan hidup berumah tangga sesuai dengan kemampuannya (suami). Sedangkan janda adalah wanita yang tidak bersuami lagi (baik karena perceraian maupun karena kematian suaminya).

Pengertian di atas, menyebutkan bahwa pemberian mantan suami berupa uang yang dibelanjakan untuk mantan istrinya, dalam Peraturan Pemerintah Nomor 10 Tahun 1983 pasal 8 ayat (1), (2), dan (3) Tentang Perkawinan dan Perceraian Pegawai Negeri Sipil, yang menyatakan dengan tegas :

1) Apabila perceraian terjadi atas kehendak pegawai negeri sipil pria maka ia wajib menyerahkan sebagian gajinya untuk penghidupan bekas istri dan anak-anaknya.

2) Pembagian gaji sebagaimana dimaksud dalam ayat (1) sepertiga untuk pegawai negeri pria yang bersangkutan, sepertiga untuk bekas istrinya, dan sepertiga untuk anak atau anak-anak.

\footnotetext{
${ }^{14}$ Ibid, Hal 149

15 Ibid, Hal 114

${ }_{17}^{16}$ Ibid, Hal 115

${ }_{17}^{17}$ Simorangkir, Et.al, Kamus Hukum, Jakarta, Sinar Grafika, 2004 Hal 102

18 Amiur Nuruddin dan Azhari Akmal Tarigan, Hukum Perdata Islam Di Indonesia,

${ }^{19}$ Poerwadarminta, Kamus Umum Bahasa Indonesia III, Jakarta, Balai Pustaka, 2007 hal
} Jakarta, Kencana, 2004 Hal 186. 
3) Apabila dalam perkawinan tersebut tidak ada anak maka bagian gaji yang wajib diberikan pegawai negeri sipil pria kepada bekas istrinya ialah setengah dari gajinya.

Peraturan pemerintah ini menghendaki dengan terjadinya perceraian, jangan sampai menimbulkan akibat kepada mantan istri setelah ditinggal suaminya, harus mencari nafkah untuk kehidupan dirinya dan anak-anaknya. ${ }^{21}$ Dalam pelaksanaan pembagian gaji milik suami tersebut, pejabat yang berwenang ikut bertanggung jawab dalam pelaksanaannya, sebagaimana dinyatakan dalam Surat Edaran Nomor : 08/SE/1983 tentang izin perkawinan dan perceraian bagi pegawai negeri sipil ditegaskan pada bagian perceraian butir 27 : “ pembagian gaji sebagai tersebut di atas, adalah menjadi kewajiban masing-masing pejabat yang bersangkutan, atau pejabat lain yang ditunjuk olehnya dan yang mendatangani daftar gaji adalah pegawai negeri sipil yang bersangkutan." 22

Tegasnya bahwa seorang pegawai negeri sipil yang melakukan perceraian wajib memberikan sebagian gajinya sebagaimana diatur dalam peraturan pemerintah, dan surat edaran di atas, dengan mekanisme memberikan kuasa kepada pejabat yang mengurusi gajinya untuk memotong dan menyerahkan sebagiannya itu kepada bekas istrinya.

Peraturan Pemerintah Nomor 10 Tahun 1983, yang dimaksud dengan pegawai negari sipil itu diterangkan pada Pasal 1,2 : Yang dipersamakan dengan pegawai negeri sipil yaitu :

a. Pegawai bulanan disamping pensiun;

b. Pegawai Bank Milik Negara;

c. Pegawai Badan Usaha Milik Negara;

d. Pegawai Bank Milik Daerah;

e. Pegawai Badan Usaha Milik Daerah;

f. Kepala Desa, Perangkat Deșa, dan petugas yang menyelenggarakan urusan pemerintahan Desa.

Penegasan pengertian pasal di atas, meliputi pegawai negeri sipil yang dimaksud dalam Undang-undang Nomor 8 Tahun 1983, tentang pokok-pokok kepegawaian. Dengan demikian, persoalan hak nafkah janda sangat diperhatikan dalam peraturan pemerintah ini, bahkan bagi pegawai negeri sipil yang melanggar undang-undang tersebut di atas, akan dikenai sanksi hukuman disiplin, dijatuhkan oleh pejabat yang berwenang, menghukum menurut ketentuan dan tata cara sebagaimana diatur dalam Peraturan Pemerintah Nomor 30 Tahun 1980. (Surat Edaran

${ }^{20}$ Undang-undang Pokok Perkawinan, Jakarta, Sinar Grafika, 2000, hal 132.

21 Anshary, Hukum Perkawinan Di Indonesia, Yogyakarta, Pustaka Pelajar, 2010, hal

109.

\footnotetext{
${ }^{22}$ Undang-undang Pokok Perkawinan, Op cit, hal 162.

${ }^{23}$ Ibid, hal 129
} 
Kepala Badan Administrasi Kepegawaian Negara Nomor 23/SE/1980 tanggal 30 Oktober 1980). 24

\section{Syarat-syarat Pemberian Nafkah Bagi Janda}

Peraturan Pemerintah Nomor 10 Tahun 1983 ayat (4), (5), dan (6) memaparkan syarat-syarat seorang janda berhak atas nafkah dari bekas suaminya, yaitu :

Ayat (4)

Apabila perceraian terjadi atas kehendak istri, maka ia tidak berhak atas bagian penghasilan dari bekas suami.

Ayat (5)

Ketentuan sebagaimana dimaksud dalam ayat (4) tidak berlaku, apabila istri meminta cerai karena dimadu.

Ayat (6)

Apabila bekas istri pegawai negeri sipil yang bersangkutan kawin lagi, maka haknya atas bagian gaji dari bekas suaminya menjadi hapus terhitung mulai kawin lagi.

Pernyataan pasal 8 ayat (4), (5) dan (6) secara tidak langsung menggambarkan bahwa seorang janda, berhak mendapatkan nafkah dari mantan suaminya, jikalau seorang janda tersebut tidak melanggar ketentuan di atas. Penjelasan tentang teknis pelaksanaan dari pasal di atas dituangkan dalam Surat Edaran Nomor : 08/SE/1983 Tentang Izin Perkawinan dan Perceraian Bagi Pegawai Negeri Sipil ditegaskan pada butir ke 20 dan 21 yaitu :

20. Hak atas bagian gaji sebagai tersebut di atas tidak berlaku apabila perceraian terjadi atas kehendak istri yang bersangkutan, kecuali karena istri yang bersangkutan meminta cerai karena dimadu, atau dengan perkataan lain, apabila istri meminta cerai karena dimadu, maka sesudah perceraian terjadi, bekas istri tersebut berhak atas gaji tersebut.

21. Apabila bekas istri yang bersangkutan kawin lagi, maka pembayaran bagian gaji itu di hentikan terhitung mulai bulan berikutnya bekas istri yang bersangkutan kawin lagi.

Peraturan Pemerintah Nomor 10 Tahun 1983 dirubah menjadi Peraturan Pemerintah Nomor 45 Tahun 1990 terdapat perubahan pada ayat (4) yang berbunyi :

a. (4) Pembagian gaji kepada bekas istri tidak diberikan apabila alasan perceraian disebabkan karena istri berzina, dan atau istri melakukan kekejaman atau penganiayaan berat baik lahir maupun batin terhadap suami dan atau istri telah meninggalkan suami selama dua tahun berturut-turut tanpa izin suami dan tanpa alasan yang sah atau karena hal lain diluar kemampuannya.

\footnotetext{
${ }^{24}$ Ibid, hal 180

${ }_{26}^{25}$ Undang-undang Pokok Perkawinan, Op cit, hal 133

${ }^{26}$ Ibid, hal 161
} 
b. Ketentuan ayat (4) lama selanjutnya dijadikan ketentuan ayat (5).

c. Mengubah ketentuan ayat (5) lama dan selanjutnya menjadi ayat

(6) baru sehingga berbunyi sebagai berikut :

(6) Ketentuan sebagaimana dimaksud dalam ayat (5) tidak berlaku, apabila istri meminta cerai karena dimadu, dan atau suami berzina, dan atau suami melakukan kekejaman dan penganiayaan berat baik lahir maupun batin terhadap istri dan atau suami menjadi pemabuk, pemadat dan penjudi yang sukar disembuhkan dan atau suami telah meninggalkan istri selama dua tahun berturut-turut tanpa izin istri dan tanpa alasan yang sah karena hal diluar kemampuannya.

d. Ketentuan ayat (6) lama selanjutnya dijadikan ketentuan ayat (7) baru.

Berdasarkan pernyataan di atas, jadi sudah jelaslah bahwa istri menerima mut'ah dari mantan suami, harus memenuhi syarat-syarat yang ada, agar tidak ada yang merasa dirugikan di antara kedua belah pihak, yang ketika menjadi suami istri sudah terbiasa dengan hak dan kewajibannya masing-masing. ${ }^{28}$ Tentunya dikarenakan sebelumnya terjadi masalah di antara mereka yang menyebabkan perceraian.

\section{Analisis}

\section{Pengertian Nafkah}

Nafkah menurut Islam adalah memenuhi kebutuhan makanan, tempat tinggal, jelasnya nafkah merupakan pemberian dari suami yang wajib kepada istri, karena ikatan perkawinan yang sah. Besarnya nafkah berdasarkan keadaan ekonomi suami dan tidak bisa dipaksakan sesuai dengan kehendak istri.

Menurut fiqh madzhab (Hanafi, Maliki, Syafi'i dan Hambali) sepakat bahwa nafkah lebih ditekankan kepada makanan (pangan), pakaian (sandang), tempat tinggal (papan). Namun dalam perundang-undangan di Indonesia esensi dari nafkah terkait erat dengan masalah uang, status sosial, cara hidup serta perubahan situasi dan kondisi. Sehingga nafkah bisa berkembang pada segala sesuatu yang berkaitan dengan kebutuhan hidup yang rasional

Nafkah menjadi suatu hal yang bersifat elastis dan fleksibel tergantung kondisi yang melingkupinya berupa kenyataan sosial dan perkembangan kebutuhan hidup manusia serta kondisi riil dari kehidupan pasangan suami istri dalam perkawinan. Jadi nafkah bisa juga berupa biaya rumah tangga, biaya perawatan, dan pengobatan bagi istri.

\section{Jenis Nafkah}

${ }^{27}$ Undang-Undang Tentang Perkawinan Dan Hukum Islam, Bandung, Citra Umbara, 2012 Hal 88

${ }^{28}$ Amir Syarifuddin, Hukum Perkawinan Islam di Indonesia, Jakarta, Prenada Media, 2006. hal, 160 
Berdasarkan pendapat fiqh madzhab (Hanafi, Maliki, syafi'i dan Hambali), istri yang sedang menjalani masa iddah mendapatkan nafkah dan tempat tinggal. Menurut Hanafi Nafkah yang diterima istri meliputi makanan, daging, sayur mayur dan buah-buahan. Serta kebutuhan lain yang diperlukan dalam kehidupan sehari-hari. Standar ini berbeda menurut keadaan dan situasi setempat. Pendapat Imam Hanafi ini tidak memiliki perbedaan dengan Imam Malik dan Hambali, bahwa hukum syara' tidak menentukan besarnya nafkah.

Syafi'i memiliki pendapat yang berbeda dengan ketiga Imam di atas (Hanafi, Maliki dan Hambali). Imam syafi'i menetapkan jumlah nafkah tidak diukur dengan jumlah kebutuhan, tetapi diukur hanya berdasarkan hukum syara', yaitu apabila suami kaya maka diwajibkan memberi nafkah setiap harinya dua mud gandum, sedangkan yang miskin hanya diwajibkan memberi satu mud gandum, setiap harinya.

Berbeda dengan Peraturan Pemerintah Nomor 10 Tahun 1983 Tentang Izin Perkawinan dan Perceraian Pegawai Negeri Sipil, yang mengatur tentang nafkah, terdapat pada pasal 8 ayat (1), (2) dan (3) yang berbunyi:

1) Apabila perceraian terjadi atas kehendak pegawai negeri sipil pria maka ia wajib menyerahkan sebagian gajinya untuk penghidupan bekas istri dan anak-anaknya.

2) Pembagian gaji sebagaimana dimaksud dalam ayat (1) sepertiga untuk pegawai negeri pria yang bersangkutan, sepertiga untuk bekas istrinya, dan sepertiga untuk anak atau anak-anak.

3) Apabila dalam perkawinan tersebut tidak ada anak maka bagian gaji yang wajib diberikan pegawai negeri sipil pria kepada bekas istrinya ialah setengah dari gajinya.

Berdasarkan pasal di atas, istri yang diceraikan suaminya berhak mendapatkan sepertiga gaji jika ada anak dan jika tidak ada anak, maka mantan istri tersebut berhak mendapatkan setengah dari gaji suami yang berupa uang. Jadi dengan demikian jenis nafkah yang diterima istri pasca perceraian, adalah gaji yang berupa uang.

\section{Waktu Pemberian Nafkah}

Menurut madzhab fiqh, nafkah dan tempat tinggal untuk istri yang tertalak oleh suaminya khususnya talak raj'i, memiliki batas waktu tertentu, yaitu pada saat masa iddahnya saja, selebihnya dari pada itu, istri tidak memiliki hak mendapatkan nafkah dan tempat tinggal, sehingga status istri yang sudah menjadi janda ini sangat memprihatinkan, akibat dari talak yang diucapkan suami, terhadap istrinya tersebut.

Berbeda dengan Peraturan Pemerintah Nomor 10 Tahun 1983, Tentang Izin Perkawinan dan Perceraian Pegawai Negeri Sipil, yang lebih memperhatikan nasib seorang janda setelah dicerikan oleh suaminya, yang berkerja sebagai pegawai negeri sipil, hal ini didasarkan pada Pasal 8 yang berbunyi : 
1) Apabila perceraian terjadi atas kehendak pegawai negeri sipil pria maka ia wajib menyerahkan sebagian gajinya untuk penghidupan bekas istri dan anak-anaknya.

2) Pembagian gaji sebagaimana dimaksud dalam ayat (1) sepertiga untuk pegawai negeri pria yang bersangkutan, sepertiga untuk bekas istrinya, dan sepertiga untuk anak atau anak-anak.

3) Apabila dalam perkawinan tersebut tidak ada anak maka bagian gaji yang wajib diberikan pegawai negeri sipil pria kepada bekas istrinya ialah setengah dari gajinya.

4) Apabila perceraian terjadi atas kehendak istri, maka ia tidak berhak atas bagian penghasilan dari bekas suami.

5) Ketentuan sebagaimana dimaksud dalam ayat (4) tidak berlaku, apabila istri meminta cerai karena dimadu.

6) Apabila bekas istri pegawai negeri sipil yang bersangkutan kawin lagi, maka haknya atas bagian gaji dari bekas suaminya menjadi hapus terhitung mulai kawin lagi

Berdasarkan pernyataan di atas istri berhak mendapatkan sebagian gaji dari pihak suami, yang mana gaji tersebut akan keluar setiap bulannya. Sehingga tidak ada limit atau batas waktu tertentu dalam hal pemberian nafkah kecuali bila istri menikah dengan orang lain, maka pembagian gaji terhadap istri akan diberhentikan. Peraturan pemerintah ini, tentu dapat menjadi inspirasi bagi para pembuat hukum, untuk dapat membuat hukum positif, tentang pemberian nafkah janda. Dalam hal ini bukan hanya jandanya pegawai negeri sipil saja, yang tidak memiliki batasan waktu, tetapi semua janda yang diceraikan oleh suaminya. Sehingga dapat menjadi pelajaran bagi para suami yang akan menceraikan istrinya.

\section{Bentuk Perceraian}

Hukum Islam memandang kasus perceraian dengan talak raj'i, baik dari perspektif fiqh tradisional maupun kompilasi hukum Islam menetapkan bahwa perempuan mempunyai hak nafkah secara penuh, yang harus ditunaikan suami selama periode iddah. Berbeda halnya dengan bentuk perceraian yang dilakukan dengan talak ba'in.

Ketetapan perundang-undangan, khususnya peraturan pemerintah nomor 10 tahun 1983, Tentang Izin Perkawinan dan Perceraian Pegawai Negeri Sipil, tidak memandang dari bentuk perceraiannya, tetapi lebih kepada siapa yang ingin bercerai. Hal ini tertuang pada Pasal 8 ayat (4), (5), dan (6) yaitu :

Ayat (4)

Apabila perceraian terjadi atas kehendak istri, maka ia tidak berhak atas bagian penghasilan dari bekas suami.

Ayat (5)

Ketentuan sebagaimana dimaksud dalam ayat (4) tidak berlaku, apabila istri meminta cerai karena dimadu.

Ayat (6) 
Apabila bekas istri pegawai negeri sipil yang bersangkutan kawin lagi, maka haknya atas bagian gaji dari bekas suaminya menjadi hapus terhitung mulai kawin lagi.

Pernyataan pada pasal 8 ayat (4), (5), dan (6) menjelaskan bahwa seorang janda berhak mendapatkan nafkah dari mantan suaminya, jika seorang janda tersebut tidak melanggar ketentuan di atas. Tetapi Peraturan Pemerintah Nomor 10 Tahun 1983, diamandemen menjadi Peraturan Pemerintah Nomor 45 Tahun 1990 yang terdapat perubahan pada ayat (4) yang berbunyi :

d. (4) Pembagian gaji kepada bekas istri tidak diberikan apabila alasan perceraian disebabkan karena istri berzina, dan atau istri melakukan kekejaman atau penganiayaan berat baik lahir maupun batin terhadap suami dan atau istri telah meninggalkan suami selama dua tahun berturut-turut tanpa izin suami dan tanpa alasan yang sah atau karena hal lain diluar kemampuannya.

e. Ketentuan ayat (4) lama selanjutnya dijadikan ketentuan ayat (5).

f. Mengubah ketentuan ayat (5) lama dan selanjutnya menjadi ayat (6) baru sehingga berbunyi sebagai berikut :

(6) Ketentuan sebagaimana dimaksud dalam ayat (5) tidak berlaku, apabila istri meminta cerai karena dimadu, dan atau suami berzina, dan atau suami melakukan kekejaman dan penganiayaan berat baik lahir maupun batin terhadap istri dan atau suami menjadi pemabuk, pemadat dan penjudi yang sukar disembuhkan dan atau suami telah meninggalkan istri selama dua tahun berturut-turut tanpa izin istri dan tanpa alasan yang sah karena hal diluar kemampuannya.

e. Ketentuan ayat (6) lama selanjutnya dijadikan ketentuan ayat (7) baru.

Pernyataan di atas, memiliki penjelasan bahwa istri menerima nafkah tidak berhubungan dengan jenis talaknya, tetapi lebih kepada siapa yang ingin bercerai, alasan perceraiannya dan diantara kedua pasangan tersebut, siapakah yang zalim terhadap pasangan dan pernikahannya, apabila syarat-syarat di atas sudah dipenuhi oleh istri, maka istri wajib atas nafkah dari suaminya tersebut, dan hal ini tidak bertentangan dengan hukum Islam dengan dalih, arti dari pada matâ' sebagai nafkah akibat perceraian tanpa batas tertentu dilihat dari berbagai faktor yang mengitarinya.

\section{DAFTAR PUSTAKA}

Abdurrahman, Kompilasi Hukum Islam, Jakarta, Akapress, 2010.

Al Syaukani, Nailul Authar, alih bahasa Mu'ammal Hamidy, Surabaya, Bina Ilmu, 1984. 
Al-Imam Abul Fida Isma'il Ibnu Kasir Ad-Dimasyqi, Tafsir Ibnu Kasir Juz, 2 alih bahasa Bahrun Abu Bakar dan Anwar Abu Bakar, Bandung, Sinar Baru Algensindo, 2011.

Amir Syarifuddin, Hukum Perkawinan Islam di Indonesia, Jakarta, Prenada Media, 2006.

Amiur Nuruddin dan Azhari Akmal Tarigan, Hukum Perdata Islam Di Indonesia, Jakarta, Kencana, 2004.

Anshary, Hukum Perkawinan Di Indonesia, Yogyakarta, Pustaka Pelajar, 2010. Departemen Agama RI, Al-Qur'an Dan Terjemahnya, alih bahasa Ahmad Toha Putra, Semarang, Asy Syfa', 2007.

Hasan Alwi, Kamus Besar Bahasa Indonesia, Jakarta, Balai Pustaka, 2002.

Ibnu Rusyd, Bidayatul Mujtahid, alih bahasa Imam Ghazali Said dan Achmad Zainudin ,Jakarta, Pustaka Amani, 2007.

Imam Syafi'i, Ringkasan Al Umm, alih bahasa Imron Rosadi, et.al, Jakarta, Pustaka Azzam, 2012

Malik bin Anas, Al-Muwaththa', alih bahasa Nur Alim, et.al, Jakarta, Pustaka Azzam, 2006.

Muhammad Jawad Mughniyah, Figh Lima Mazhab, alih bahasa Masykur et.al, Jakarta, Lentera, 2011.

Poerwadarminta, Kamus Umum Bahasa Indonesia III, Jakarta, Balai Pustaka, 2007.

Simorangkir, Et.al, Kamus Hukum, Jakarta, Sinar Grafika, 2004.

Slamet Abidin dan Aminuddin, Fiqih Munakahat, Bandung, Pustaka Setia, 1999. Syaikh Al-Allamah Muhammad, Fiqh Empat Mazhab alih bahasa Abdullah Zaki Alkaf, Bandung, Hasyimi, 2010.

Teungku Muhammad Hasbi Ash-Shiddieqy, Tafsir Al-Qur'anul Majid, alih bahasa Semarang, Pustaka Rizki Putra, 2000.

Undang-undang Pokok Perkawinan, Jakarta, Sinar Grafika, 2000.

Wahbah az-Zuhaili, Fiqih Islam Wa Adilatuhu, alih bahasa Abdul Hayyie alKattani, et.al, Jakarta, Darul Fikir, 2011.

Wahbah Zuhaili, al-Fiqhu Asy-Syafi'i al-Muyassar alih bahasa Muhammad Afifi dan Abdul Hafiz, Jakarta, Almahira, 2010.

Wahyu Setiawan, Hak-hak Perempuan Pasca Perceraian, tidak di terbitkan, Yogyakarta, 2004 